\title{
Comprehensive Human Development Without Violence and Seclusion. Is Education A Mitigating Factor?
}

\author{
Alberto Isaac Pierdant Rodríguez \\ Metropolitan Autonomus University (Xochimilco) \\ PO box 04960, Calzada del Hueso 1100 Coyoacán, Ciudad de Mexico, Mexico
}

\begin{abstract}
For UNDP (2016), human development consists in "the creation of an environment in which people can develop their maximum potential and lead a productive and creative life according to their needs and interests". It requires the satisfaction of certain basic needs: health, education, food, housing with minimum services, an adequate income to cover them, and a freedom to express ideas and convictions.However, not only the latter is necessary for this development, violence in all its forms - intrafamiliar, of the common law (robbery, injury, homicide, property crime, kidnapping and rape), gender violence, violence generated by illicit activities (drug trafficking, fuel theft (gasoline, gas) - also directly decreases in individuals that desired human development.Among the many factors that can affect the integral human development of the individuals within a society, lack of education becomes one of these factors in all its current aspects, schooled and not schooled.The importance of this factor is such that the UNDP (2016) in its Sustainable Development Goal (SDO) for education, indicates that "... education is one of the most powerful and proven engines to guarantee sustainable development". Based on these ideas, we have taken up a research hypothesis, in which we propose to review the relationship between violence and education and verify that the latter is a mitigating factor that allows an integral human development.Violence reduction in a society, implies the presence, among other factors, of two triggers, economic and educational. The latter is for us one of the factors of study, which we consider essential to reduce violence and generate an integral human development.This research aims to prove that a higher level of education in a society results in lower levels of violence and greater integral human development. Our study society is formed by the inhabitants of the state of Oaxaca in Mexico; It includes a period of study from 2009 to 2017. This work will show the first results for this relation.
\end{abstract}

Keywords: Human development, education, violence.

DOI: $10.7176 /$ RHSS/11-11-09

Publication date:June $30^{\text {th }} 2021$

\section{Introduction}

It is estimated that annually "more than 1.4 million people lose their lives due to violence. For every one that dies, many more are left with injuries and various physical, sexual, reproductive and mental health problems. Violence places a huge burden on national economies, costing countries billions of US $\$$ annually in healthcare, law enforcement, imprisonment, and lost productivity. The WHO [World Health Organization] collaborates with its partners to prevent violence through scientifically solid strategies, conceived and applied in terms of responsible causes at the individual, family, community and social levels" (WHO, 1996). This "situation has led to the development of the" Plan of Action of the World Campaign for the Prevention of Violence 2012-2020 "of the WHO (2011), in which six national objectives are structured towards which they can oriented efforts. The first two aim to prioritize the prevention of violence on the global public health agenda; The following three are intended to establish, on solid foundations, the activities necessary to prevent violence; and the latter seeks to promote the application of evidence-based violence prevention strategies in the areas of parenting, life skills, social norms, alcohol, risk of death and injuries from firearms, and services for victims" (Pierdant et. Al., 2018).

In Mexico, an increase in violence has been observed in recent years due to various factors, including poverty, social inequality, discrimination, drug trafficking, organized crime, which have placed this problem at the forefront of this society. We argue that not only the economic income factor is responsible for this increase; since we think that among other factors, education is fundamental, to reduce, to some extent, violence, and [a consequence of it, seclusion] (Dammer, 2010). An educated society changes its vision of life, seeks other objectives that take it away from it in order to improve its standard of living through satisfactory work that allows it to obtain the minimum requirements of health, education and recreation, housing and food. This work shows an advance of a regression analysis that was carried out between the education variable (schools, school enrollment, teachers, and educational lag) and the violence variable (that of the common law) in the Mexican state of Oaxaca whose consequence in many cases is the prison. We are aware that this is not the only relationship that can explain physical and moral violence, and imprisonment, but we start from it in this study to later conclude with a multidimensional analysis. 


\section{Theoretical framework and methodology}

What do we understand by violence? Jaques Sémelin (1983 cited by Blair 2009, p. 10) points out, quite rightly, that there is no theory capable of explaining all forms of violence; it has, he says, many faces, the result of different processes. Thus, "Jean-Claude Chenais (1981 cited by Blair 2009, p. 13), proposes the following definition:

Violence in the strict sense, the only measurable and incontestable violence is physical violence. It is the direct, bodily attack against people. She has a triple character: brutal, exterior and painful. What defines it is the material use of force, rudeness voluntarily committed to the detriment of someone".

The main characteristic of this violence is the seriousness of the risk to which a victim is subjected, since it can affect his life, health, bodily integrity, or freedom. For him, there is only violence between individuals, and he does not speak of violence against property; then, violence, he says, transcends political life, and builds deep roots in the cultural life of the individual and therefore of a society.

For Jean-Marie Domenach (1980 cited by Blair 2009, p. 15), the violence that we know, we learn it from three aspects. The psychological aspect, defined as an explosion of force that takes on an irrational and often criminal aspect, leading in many cases to seclusion. The moral, observable aspect as an attack on property and freedom of the other. And finally, a political aspect, meaning the use of force to seize power or to divert it for illicit purposes. It is the definition of violence that best approximates the behavior of a current society and that as indicated by Domenach (1980 cited by Blair 2009, p. 16), violence is the use of open or hidden force, in order to obtain from an individual or a group that he or they do not want to freely consent to. The concept of violence in this work is measurable through statistics, on the one hand, and as Chenais (1981 cited by Blair 2009, p. 13) indicates, it is physical violence (injuries, homicides, robbery with violence, indecent assault and rapes), and the violence that is exercised under the moral aspect where we observe an attack on the property and freedom of the other (abuse of trust, damage to someone else's property, extortion, fraud, dispossession) (Domenach, 1980 cited by Blair 2009, p. 15), and that, as indicated, leads, in many cases, to prison. To analyze violence, the violence observed in the state of Oaxaca, in Mexico, was considered. We select the violent crimes that are reported and recorded for the period 2009 - 2017, that is, the criminal incidence of the common law, since there is violence that is not reported, or is, but in a reduced or partial way, by this society. Among these unreported crimes are: femicides, domestic violence, rape by a member of the family, social protest, blocking of roads and communication infrastructure (airports), among others.

The criminal incidence of the common law considered is that registered through statistics by the Attorney General of the Republic (PGR) (as of 2019, Fiscalía General de la República) and the Attorney General of the State of Oaxaca. The concepts considered in these are:

- Common theft (with and without violence) of house room, business, vehicles, carriers, passers-by, others; cattle theft (abigeate); robbery in banking institutions (with and without violence); highway robbery (with and without violence).

- Injuries (painful and guilty) with a knife, a firearm and others.

- Homicides (intentional and culpable) by white gun, by firearm and others.

- Abuse of trust, damage to someone else's property, extortion, fraud, dispossession (with and without violence).

- Threats, stupro and other sexual offences.

- Kidnappings and rapes.

The behavior of these variables for the study period is shown in table 1 and graph 1 .

Based on these ideas, the research hypothesis used indicates that the levels of physical and moral violence in a society increase as it has lower levels of education and access to information, which is aggravated, if this part of society reaches the state or federal prisons, because in them, there is no priority, formal or informal school training on behalf of the inmate, both for the female and male prison population. We consider that an individual who has a minimum schooling ( 1 or 2 years of preschool, 6 years of primary and 3 of secondary) can act and adapt better to information societies, than one who does not have this basic training. Of course, an education higher than the indicated minimum (high school, university and graduate studies) mostly reduce their personal and social rates of violence and detention. However, not only the educational variable leads to these behaviors, Pierdant (2018) analyzes "social and educational inequality in two states of Mexico (Nuevo León and Oaxaca) multidimensionally through seven variables (income -individual and family-, education -individual and family-, access to housing, quality of housing (housing with minimum services: water, electricity, sanitation, drainage), access to health services, access to social security and access to adequate and quality food) ". Their lack, in one form or another, also generate elements for physical and moral violence in any society. This multidimensional analysis will allow new variables to be integrated into the next stages of this research for the analysis of this problem.

For this analysis, education is a fundamental factor, it is an instrument that promotes integral human development, as we have already indicated; for this reason, we have considered it constituted by the following 
educational components.

- Number of educational institutions in the state (schools).

- Number of students in the state education system.

- Number of teachers in the state education system.

- Educational lag in the homes of the state. ${ }^{1}$

The behavior of these educational variables for Oaxaca in the study period is shown in table 2 and graphs 2, 3 and 4.

\section{First results}

The growth of violence in a society such as Oaxacan may be due, among other factors, to a reduction in the schooling of its population. We can see strong growth in the criminal incidence in the state between 2010 and 2013 despite some stability in the behaviour of educational variables. There is no growth in the number of schools and teachers in the state education system for the study period. The former are around 11,000 schools and the latter in an average of 50,000 teachers per school year. ${ }^{2}$ In the event of no educational growth, there is a growth in violence, mainly in the crimes of theft, property crimes, injuries, and other crimes (table and graph 1). This increase in violence is linked in those years to erratic school enrolment behavior that decreases in 2011 (1.37\%) 2013 (-3.91\%). Despite a downward trend in the crime incidence in the state in 2017, school enrollment is drastically reduced in the school year for that year (-6.16\%), going from just over 1,084,000 students (20162017 ) to just over $1,018,000$ students (2017-2018), around 66,000 fewer students from one school year to another. The latter also generates growth in the educational lag of the state's families (chart 4), moving from a maximum educational lag of little more 1,162,000 people in 2010, to 1,074,000 people in 2013 and rebound again in 2017 to just over $1,122,000$ people.

We also elaborate in this first approximation a first set of regression models that will explain these relationships. Table 3 shows the results obtained.

In Table 3 we observe that a growth in school infrastructure $(\beta=-44.74)$ and the number of teachers $(\beta=-$ 3.26 ) in the system would generate a decrease in crime rates in the state, mainly, if emphasis is placed on the increase in schools. The correlation between these variables and total crimes are relatively strong, $R=0.681$ and $\mathrm{R}=0.635$, respectively.

Even though school enrollment and educational lag do not show a strong correlation with crime rates, $\mathrm{R}=$ 0.12 and $\mathrm{R}=0.174$, respectively; an increase in enrollment $(\beta=-0.056)$ would produce a reduction in violence, and an increase in the educational gap $(\beta=0.068)$ of the state population also produces an increase in it. The latter indicates model, educational lag shows a direct relationship with violence, that is, a greater lag generates more violence and conversely, a lower lag, less violence.

\section{Observations and conclusions}

An increase in crime rates is observed when the educational variables considered do not grow or decrease; there are increases in violence if the educational infrastructure does not grow. The same is observed, if the number of teachers in the system does not grow either, but the most serious thing is the considerable decrease in school enrolment observed in the last years of the study.

We believe that a society with a basic and informed education reduces individual and social violence to some extent, and that it can have significant repercussions such as loss of freedom.

The relationship studied between these two variables explains a part of the behavior of violence in this society, so this initial analysis must be complemented with others to achieve a broader understanding of this problem. However, these first results allowed us to obtain the following conclusions.

- There is, at least for this society, a strong relationship between the criminal impact of the common law and some variables relating to education.

- A strong basic education appears to allow for a decline in violence in these crimes.

- A greater number of schools promotes $(\beta=-44.74)$ a reduction in this type of violence.

- A growth in school enrolment $(\beta=-0.056)$ also reduces violence and imprisonment. But a reduction in this, such as that seen in recent school years, can significantly impact its increase.

- A growth in the number of teachers in the education system is also a factor in reducing these crimes in this society $(\beta=-3,268)$.

- If the previous educational elements are present, a slight growth in the educational lag ( $(B=-0.068)$ would lead to an increase in crimes in the state, apparently less access to education, more violence and imprisonment.

- There will not be an integral human development in a society, at least in the society of the state of Oaxaca, if variable education, and all its components, are not adequately addressed, with the importance they represent for development, by governments and the institutions in charge. 
- A quality basic education will reduce the current educational gap and the incidence of crime in this society, reducing at the same time, as indicated by the WHO, the high costs of care that its combat represents and consequences such as imprisonment.

\section{References}

Blair T. Elsa (2009). Aproximación teórica al concepto de violencia: avatares de una definición. Política y Cultura, otoño 2009, núm. 32, págs. 9 - 33.

Consejo Nacional de Evaluación de las Políticas Públicas (CONEVAL). Anexo estadístico por entidades: Medición de la Pobreza, Estados Unidos Mexicanos 2010 - 2016 (cuadro 21/ Oaxaca). CONEVAL, México. CONEVAL, México. (2010). Metodología para la medición multidimensional de la pobreza en México.

Chenais Jean-Claude (1981). Histoire de la violence. París, Francia: Editor Robert Laffond.

Dammer Lucia (2010). Can Education Reduce Violent Crime? Americas Quarterly. Recuperado el 7 de febrero de 2017, de http://www.americasquarterly.org/node/1897

Domenach Jean-Marie (1980). La violence, en Le violence et ses causes. París, Francia: UNESCO.

Organización Mundial de la Salud (WHO) (1996). Prevención de la violencia y los traumatismos. Recuperado el 7 de febrero de $2018 \mathrm{de}$, http://www.who.int/violence_injury_prevention/violence/es/

(2011). Plan de Acción de la Campaña Mundial de Prevención de la Violencia 2012-

2020. Recuperado el 7 de febrero de $2017 \quad$ de,
http://www.who.int/violence_injury_prevention/violence/global_campaign/actionplan/es/

Pierdant A. (2018). Análisis multidimensional de la desigualdad social y educativa en los estados de Nuevo León y Oaxaca, México, 2008 y 2010. Universidad Autónoma Metropolitana -Xochimilco, México. Págs. $10,87$.

Pierdant A., Rodríguez J., Narro A., Ramírez V y Pierdant C. A. (2018). Una primera aproximación a la relación entre educación y violencia en una sociedad. El caso de Oaxaca, México, 2008-2014. Ponencia: XVI Congreso Internacional de Análisis Organizacional (CIAO XVI). REMINEO -Universidad de Montreal (HEC), Montreal, Canadá.

PNUD (2016). Informe Nacional de Desarrollo Humano Guatemala 2015/2016. Recuperado el 20 de octubre de 2018 de, http://desarrollohumano.org.gt/desarrollo-humano/concepto/

Objetivo de Desarrollo Sostenible para la educación (número 4). Recuperado el 20 de octubre de 2018 de, http://www.mx.undp.org/content/mexico/es/home/sustainable-development-goals/goal-4-qualityeducation.html

Procuraduría General de la República (PGR). Incidencia delictiva del fuero común, estadísticas de 2008, 2010, 2012, 2014, 2015, 2016 y 2017. PGR, Ciudad de México, México.

Procuraduría General del Estado de Oaxaca. Incidencia delictiva del fuero común, estadísticas de 2008, 2010, 2012, 2014 y 2015. PGEO, Oaxaca, México.

Rodríguez J., Pierdant A. y Rodríguez C. (2010). Estadística Aplicada II. Estadística en administración para la toma de decisiones. Grupo Editorial Patria, México. Págs. 138 - 186.

Secretaría de Educación Pública (SEP) Sistema Educativo de los Estados Unidos Mexicanos. Principales cifras para el ciclo escolar 2009 - 2010, México.

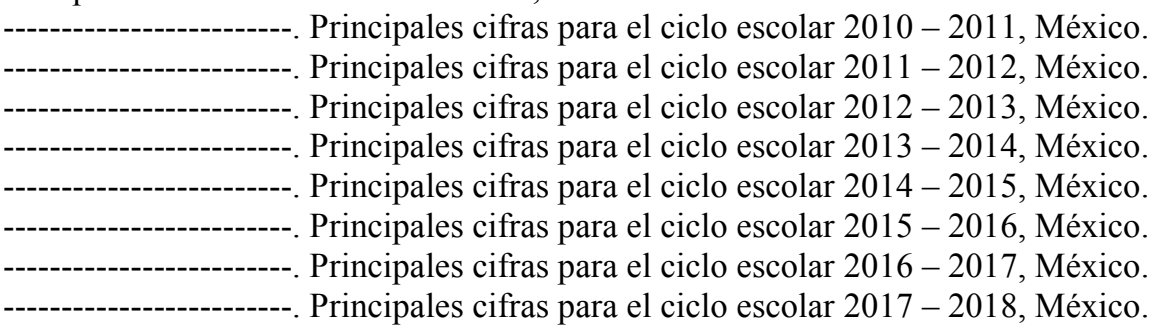

Sémelin Jaques (1983). Pour sortir de la violence. Paris, Francia: Les édition ouvriéres.

\section{Notes}

Note 1. Pierdant (2018) "Educational lag is defined as the average gap between compulsory and real education at home. This lag is measured based on the provisions of Article 3 of the Political Constitution of the United Mexican States and Articles 2, 3 and 4 of the General Education Law (LGE), which indicate the requirement, for the entire population, of attend preschool (1 year), primary (6 years) and secondary (3 years); degrees that constituted basic education until 2012 (CONEVAL, 2010, p. 53). Starting this year, a new threshold was established, the compulsory baccalaureate (3 years).

Note 2. School year: In Mexico school years begin in August or September of a year and end in July of the following year (200 days of school). 


\section{Table 1}

The criminal incidence of the common law

OAXACA

\begin{tabular}{|c|c|c|c|c|c|c|c|c|c|c|}
\hline & 2008 & $2009^{*}$ & 2010 & $2011^{*}$ & 2012 & $2013^{*}$ & 2014 & 2015 & 2016 & 2017 \\
\hline Grand total & 27,150 & 35,648 & 56,846 & 52,808 & 50,272 & 49,255 & 34,626 & 34,156 & 30,611 & 30,915 \\
\hline Common theft & 7,758 & 10,186 & 13,109 & 12,178 & 11,247 & 11,020 & 10,792 & 10,940 & 9,919 & 10,887 \\
\hline Injuries & 4,915 & 6,453 & 8,682 & 8,065 & 7,299 & 7,151 & 5,209 & 5,489 & 4,440 & 4,484 \\
\hline Homicides & 913 & 1,199 & 842 & 782 & 774 & 758 & 1,405 & 1,740 & 1,541 & 1,662 \\
\hline Property crimes ${ }^{4}$ & 5,146 & 6,757 & 12,727 & 11,823 & 9,146 & 8,961 & 5,113 & 4,843 & 5,986 & 4,683 \\
\hline Other crimes & 8,194 & 10,759 & 21,235 & 19,727 & 21,608 & 21,171 & 11,806 & 10,721 & 8,246 & 8,764 \\
\hline $\begin{array}{l}\text { Kidnappings and } \\
\text { rapes }\end{array}$ & 224 & 294 & 251 & 233 & 198 & 194 & 301 & 423 & 479 & 435 \\
\hline
\end{tabular}

* Own estimate.

Source: Own elaboration with data from Incidencia Delictiva del Fuero Común 2008, 2010, 2012, 2014, 2015, 2016 y 2017, Procuraduría General de la República (PGR) y Procuraduría General de Justicia del Estado de Oaxaca.

Table 1 shows the behavior of the crime incidence variables of the common law in Oaxaca for the period 2008 to 2017.

Table 2. Oaxaca: educational indicators 2009-2017

\begin{tabular}{cccccccc}
\hline School year & Schools & \multicolumn{3}{c}{$\begin{array}{c}\text { Students in the } \\
\text { state education } \\
\text { system }\end{array}$} & $\%$ & $\begin{array}{c}\text { Teachers in the } \\
\text { state education } \\
\text { system }\end{array}$ & \multicolumn{2}{c}{$\begin{array}{c}\text { Educational lag in } \\
\text { the homes of the } \\
\text { state }\end{array}$} \\
\hline $2009-2010$ & 10,767 & --- & $1,033,493$ & --- & 50,989 & --- & $1,129,102$ \\
$2010-2011$ & 10,853 & 0.80 & $1,048,316$ & 1.43 & 51,597 & 1.19 & $1,162,300$ \\
$2011-2012$ & 10,840 & -0.12 & $1,033,962$ & -1.37 & 52,265 & 1.29 & $1,111,360$ \\
$2012-2013$ & 10,966 & 1.16 & $1,072,892$ & 3.77 & 53,954 & 3.23 & $1,087,900$ \\
$2013-2014$ & 10,887 & -0.72 & $1,030,939$ & -3.91 & 53,494 & -0.85 & $1,074,192$ \\
$2014-2015$ & 11,028 & 1.30 & $1,048,436$ & 1.70 & 54,837 & 2.51 & $1,085,200$ \\
$2015-2016$ & 11,151 & 1.12 & $1,068,450$ & 1.91 & 56,631 & 3.27 & $1,103,648$ \\
$2016-2017$ & 11,199 & 0.43 & $1,084,938$ & 1.54 & 56,329 & -0.53 & $1,103,800$ \\
$2017-2018$ & 11,157 & -0.38 & $1,018,117$ & -6.16 & 55,268 & -1.88 & $1,122,565$ \\
\hline
\end{tabular}

Source: Sistema Educativo de los Estados Unidos Mexicanos (Secretaría de Educación Pública).

Principales cifras por ciclo escolar: 2009-2010, 2010-2011,.., 2017-2018.

CONEVAL (Consejo Nacional de Evaluación de la Política de Desarrollo Social).

Table 2 shows the educational indicators used in the model and the percentage growth from one school year to another.

\section{Table3}

Regression

models

\begin{tabular}{|c|c|c|c|c|c|c|c|}
\hline $\begin{array}{l}\text { Dependent } \\
\text { variable }\end{array}$ & $\begin{array}{c}\text { Constant } \\
(\mathrm{C})\end{array}$ & $\begin{array}{c}\text { Independent } \\
\text { variable }\end{array}$ & equation & $\begin{array}{c}\beta \\
\text { (beta) }\end{array}$ & $\mathrm{R}$ & $\mathrm{t}$ & $\mathrm{F}$ \\
\hline $\begin{array}{l}\text { Total } \\
\text { Offenses } \\
\text { Total }\end{array}$ & 533055.53 & Schools & T. Offenses $=\mathrm{C}+\beta \mathrm{Sch}$ & -44.74 & 0.681 & -2.460 & 6.054 \\
\hline $\begin{array}{l}\text { Offenses } \\
\text { Total }\end{array}$ & 100442.3 & Students & $\begin{array}{l}\text { T. Delitos }=C+\beta \text { Stude } \\
\text { T. Delitos }=C+\beta\end{array}$ & -0.056 & 0.120 & -0.320 & 0.103 \\
\hline $\begin{array}{l}\text { Offenses } \\
\text { Total }\end{array}$ & 217956.36 & Teachers & Teach & -3.268 & 0.635 & -2.176 & 4.74 \\
\hline Offenses & -33640.7 & Educational lag & T. Delitos $=\mathrm{C}+\beta \mathrm{El}$ & 0.068 & 0.174 & 0.469 & 0.220 \\
\hline
\end{tabular}

Source: Authors.

Table 3 contains the results of regression models and their equations. 


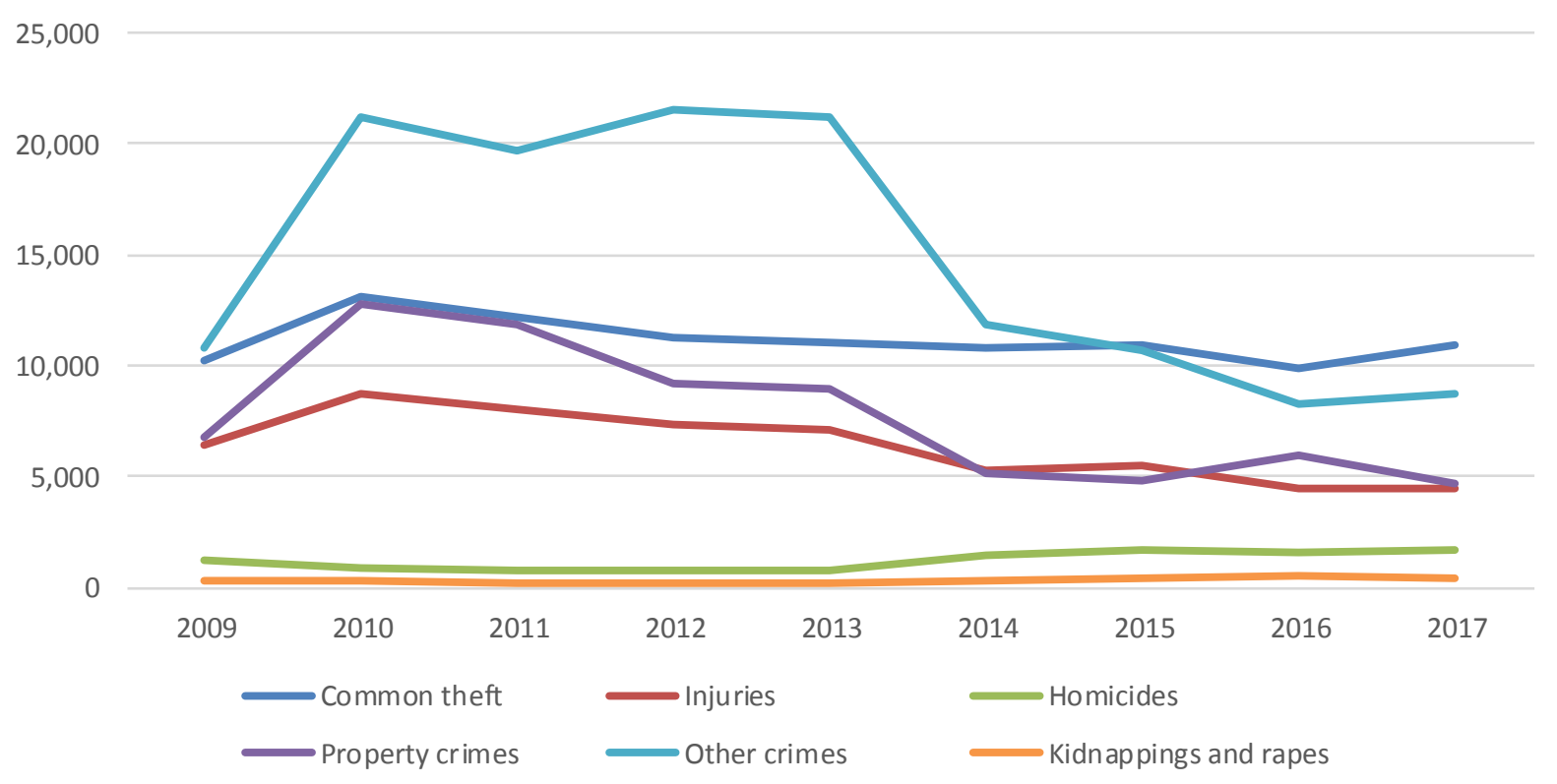

Graph 1 Criminal incidence of the common law in Oaxaca

Graph 1 shows the behavior of the crime incidence variables of the common law in Oaxaca for the period 2009 to 2017.

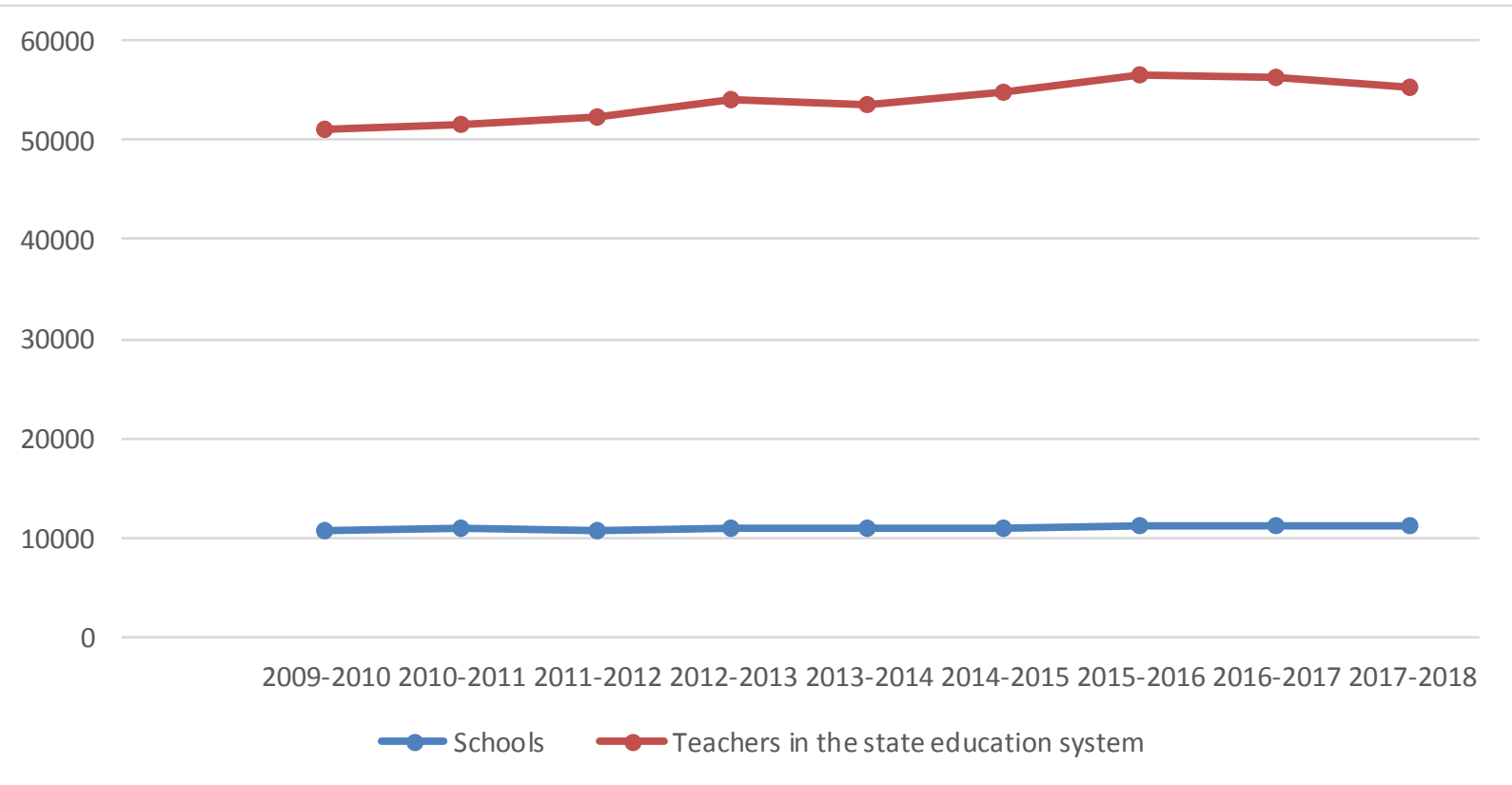

Graph 2 Schools and teachers by school year in Oaxaca

Graph 2 shows the behavior of the schools and teachers by school year in Oaxaca. 


\section{Students in the state education system}

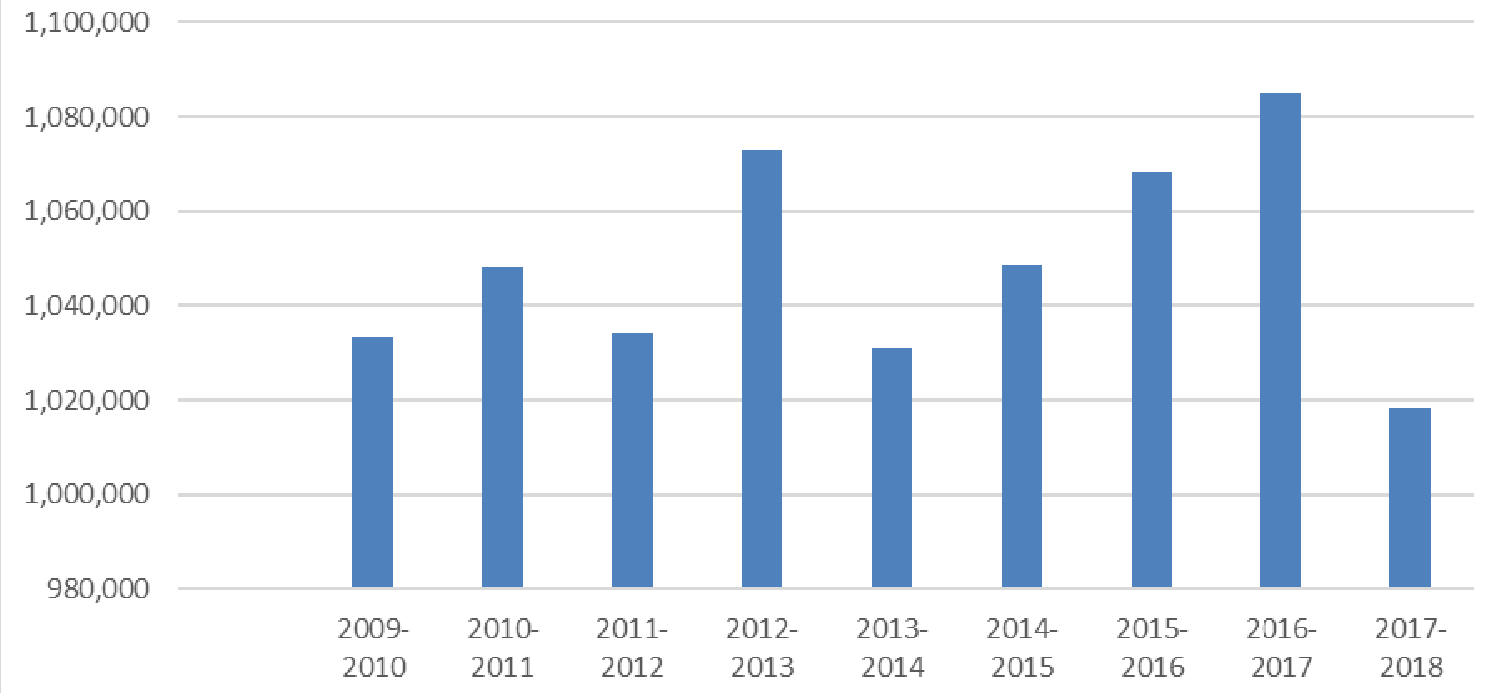

Graph 3 Students in the state education system

Graph 3, school enrollment is drastically reduced in the school year 2017-2018 (-6.16\%), going from just over $1,084,000$ students (2016-2017) to just over 1,018,000 students (2017-2018), around 66,000 fewer students from one school year to another. Lower schooling could increase the incidence of crime in the future.

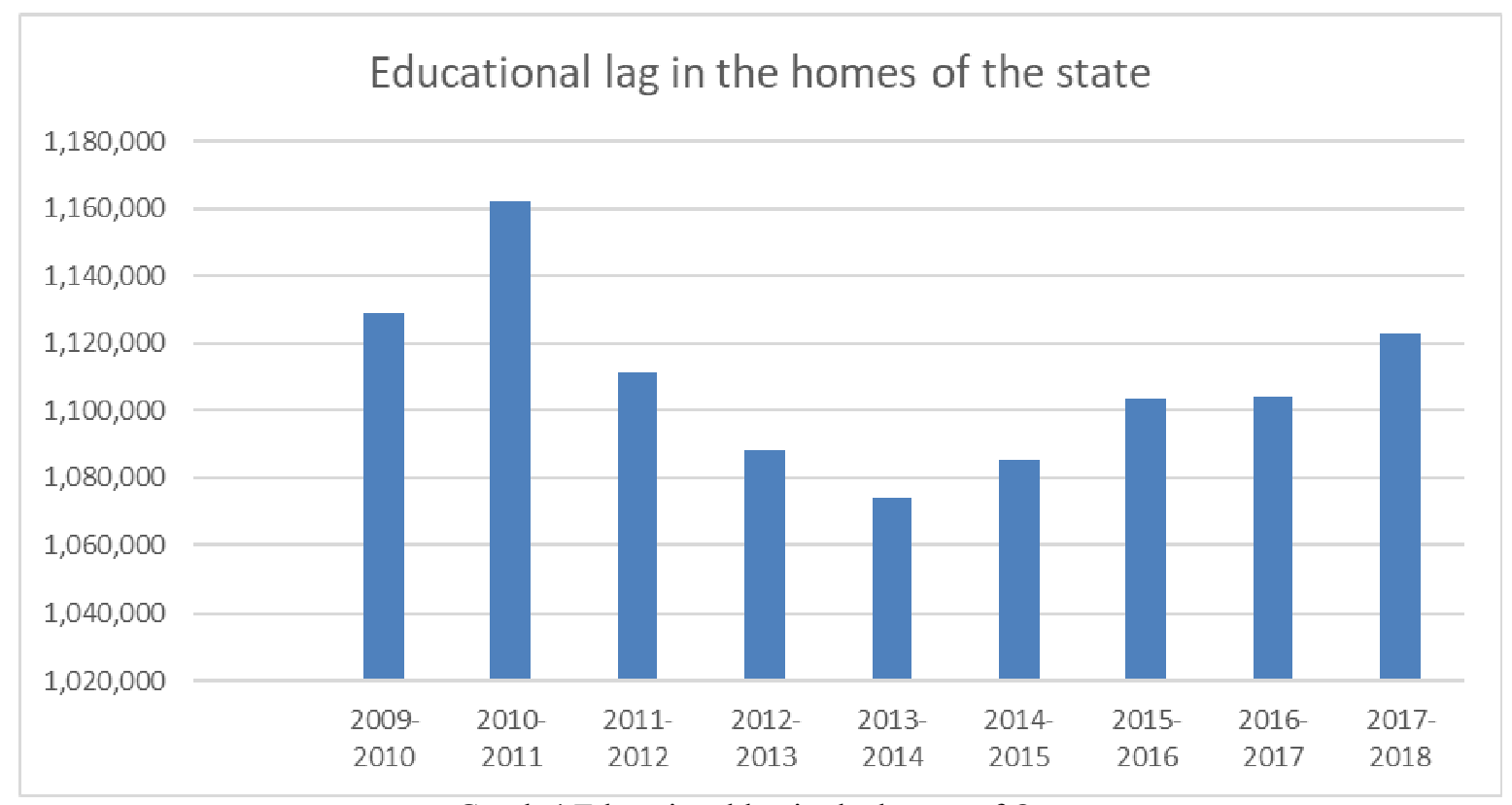

Graph 4 Educational lag in the homes of Oaxaca

Graph 4 shows the behavior of the educational lag in Oaxaca. A decrease in school enrollment (2017-2018) is related to a growth in educational lag in the state. 